\title{
Effects of Salicylic Acid on Fatty Acid Gene Expression in Carthamus tinctorious L. cv. Dinçer under Pendimethalin Stress
}

\author{
Ekrem Akbulut* \\ Malatya Turgut Özal University, Department of Bioengineering, 44200 Malatya, Turkey \\ *ekrem.akbulut@ozal.edu.tr iD \\ Received date: 13.08.2020, Accepted date: 06.12.2020
}

\begin{abstract}
Pendimethalin is a member of the dinitroaniline class herbicide. It used to control most annual grasses and many annual broad-leaved weeds. Salicylic acid acts as an endogenous signal molecule in charge of inducing environmental stress tolerance in plants. Omega- 3 fatty acid desaturase is a key enzyme for $\alpha$-linolenic acid biosynthesis. Here, we searched to understand the beneficial impacts of salicylic acid on fatty acid desaturase gene (FAD3 and FAD7) expression during pendimethalin stress in safflower (Carthamus tinctorious cv. "Dinçer). In this study, 0.004 and 0.01 $\mathrm{M}$ pendimethalin was applied to safflower plants grown under controlled climatic conditions in 36 pots. $0.05 \mathrm{mM}$ salicylic acid was applied to the samples where pendimethalin was applied. After application, gene expression analyze were performed using quantitative polymerase chain reaction. The floor change between the test and control groups was calculated with the formula $2^{\wedge}$ (delta delta CT). The change between gene expression levels was evaluated by $\mathrm{t}$ test (p <0.05). FAD3 and FAD7 expression levels decreased at low pendimethalin concentration. A down-regulation in $F A D 3$ expression was observed in high pendimethalin stress, while an up-regulation in $F A D 7$ expression was detected. Salicylic acid had a ameliorative effect on the negative effect of pendimethalin stress on FAD3 and FAD7 gene expression.
\end{abstract}

Keywords: Carthamus tinctorious, omega-3 fatty acid, pendimethalin, salicylic acid

\section{Salisilik Asidin Pendimethalin Stresi Altında Carthamus tinctorius L. cv. Dinçer'in Yağ Asidi Genlerinin İfade Düzeyi Üzerindeki Etkileri}

\section{$\ddot{\mathbf{O} z}$}

Pendimethalin dinitroanilin sınıfi bir herbisittir. Pendimethalin genellikle tek yıllık otsu bitkiler ve birçok geniş yapraklı ot ile mücadelede kullanılır. Salisilik asit bitkilerde çevresel stres toleransını indüklemekten sorumlu endojen bir sinyal molekülü olarak rol oynamaktadır. Omega-3 yağ asidi desatüraz, $\alpha$-linolenik asit biyosentezi için anahtar bir enzimdir. Bu çalışmada salisilik asidin aspirde (Carthamus tinctorius L. cv. Dinçer) pendimethalin stresi altında yağ asidi desatüraz genlerinin ifade düzeyi üzerindeki etkileri araştırıldı. Çalışmada 36 saksıda kontrollü iklim koşullarında yetiştirilen aspir bitkilerine 0.004 ve $0.01 \mathrm{M}$ pendimethalin uygulanmıştır. Pendimethalin uygulanan bitkilere sonrasında $0.05 \mathrm{mM}$ salisilik asit uygulanmıştır. Uygulama sonrasında RNA izolasyonu, cDNA sentezi ve kantitatif polimeraz zincir reaksiyonu yapılmıştır. Test ve kontrol grupları arasındaki kat değişimi $2^{\wedge}$ (delta delta CT) formülü ile hesaplanmıştır. Gen ifade düzeyleri arasındaki değişim $\mathrm{t}$ testi ile değerlendirildi $(\mathrm{p}<0.05)$. FAD3 ve $F A D 7$ ekspresyon seviyeleri düşük pendimethalin konsantrasyonunda azalmıştır. Yüksek pendimethalin stresinde FAD3 ekspresyonunda aşağı regülasyon gözlenirken, FAD7 ekspresyonunda yukarı regülasyon tespit edilmiştir. Salisilik asidin pendimetalin stresinin $F A D 3$ ve $F A D 7$ gen ifadesi üzerindeki olumsuz etkisini iyileştirici bir etki gösterdiği gözlemlenmiştir.

Anahtar Kelimeler: Carthamus tinctorious, omega-3 yağ asidi, pendimethalin, salisilik asit

\section{INTRODUCTION}

Pesticides are used to prevent or inhibit the growth of various agricultural pests that can damage crops and reduce farm productivity (Kaur, 2019). The use of herbicides can generate stress conditions, evidenced by the increase in phytotoxicity, which affects growth, development and productivity (Agostinetto et al., 2016). Pendimethalin (PEN) is a pre-emergence herbicide used for control of annual grasses and annual broad-leaved weeds (Tomlin, 2001). It is the third largest selective herbicide in the world and has been classified as a possible human 
carcinogen (Hou et al., 2004; Osman et al., 2016). Vegetable oils are significant economically because they are renewable resources of highly reduced carbon and used in diets and industrial applications (Heppard et al., 1996; Yang and Xu, 2007). Fatty acid desaturases (FADs) are play a key role in the maintenance of the proper structure and functioning of biological membranes (Los and Murata, 1998). In plants, $\omega-3$ fatty acid desaturases (FAD3 and $F A D 7$ ) are involved in the production of $\alpha$-linolenic acid (ALA) (Xue et al., 2018).

Safflower (Carthamus tinctorius L.) is an annual herbaceous plant that is adapted to hot and dry environments (Pahlavani et al., 2004; Dajue and Mündel, 1996). The plant has been grown as a source of vegetable oil used for food and industrial purposes (Dajue and Mündel, 1996; Majidi et al., 2011). Systemic acquired resistance is an immune response of plants that provides protection to infection by pests and pathogens (Fu and Dong, 2013; Andersen et al., 2018). Salicylic acid (SA) is a plant hormone that plays a role in the induction and regulation of metabolic responses to biotic and abiotic stresses (Maruri-Lopez et al., 2019).

This research was aimed to evaluate the potential role of SA on FAD 3 and FAD7 gene expression of Carthamus tinctorious cv. "Dinçer" under pendimethalin stress.

\section{MATERIAL AND METHOD}

\section{Stress Treatments and Growth Conditions}

In the present study, commercial form of PEN herbicide was used. Dinçer seeds were provided from Transitional Zone Agricultural Research Institute, Eskişehir. The seeds were grown at $23 \pm 2{ }^{\circ} \mathrm{C}$ in plant growth chamber with $60-65 \%$ humidity. Plastic pots $(10.5 \times 8 \mathrm{~cm}$ diameter and volume $0.46 \mathrm{~L})$ containing soil were used. A total of 36 samples (pots) with 3 replicates in 6 groups were created for each gene. Samples were irrigated every 3 days with Hoagland culture solution (Hoagland and Arnon, 1938). PEN was applied after germination at the doses determined $(0.004$ and $0.01 \mathrm{M})$ following toxicity tests to the leaves of plants of suitable size ( 21 days). PEN was applied by spraying method. The application samples were divided into six groups as follows (Group 1) Control, (Group 2) SA Control; (Group 3) $0.004 \mathrm{M}$ PEN, (Group 4) 0,004 M PEN+0.5 mM SA; (Group 5) $0.01 \mathrm{M}$ PEN; (Group 6) 0.01 M PEN+0.5 mM SA.

\section{RNA Isolation}

Samples were taken from safflower leaves at 24, 48 and 72 hours after chemical application and frozen in liquid nitrogen. Frozen samples were taken into homogenization tubes and $600 \mu 1$ lysis buffer (RLT) was added. $100 \mathrm{mg}$ sample of frozen material was homogenized for 1 minute at $7 \mathrm{~m} \mathrm{~s}^{-1}$ with $2.5 \mathrm{~mm}$ ceramic beads in an eppendorf tube (Bioprep 24). Samples were incubated at $56^{\circ} \mathrm{C}$ for 30 minutes in a water bath. The samples were centrifuged at 16,000 rpm for 2 minutes and the supernatant was taken into a new eppendorf tube. RNA isolation was performed according to the manufacturer's instructions (QIAGEN, Allprep Mini Kit Cat No:80004).

\section{cDNA Synthesis}

The quality of mRNA obtained after RNA isolation was checked by spectrophotometer. RNA isolation was repeated from the samples with total RNA concentration below $4 \mu \mathrm{g} \mathrm{mL} \mathrm{m}^{-1}$. In the examples, the conversion kit (QIAGEN, RT2 HT First Strand Kit, Cat No: 330411) was used for DNA elimination and a rapid first chain cDNA synthesis. cDNA synthesis was carried out by holding the reaction components at thermal cycler for $42^{\circ} \mathrm{C}$ at 15 minutes and at $95^{\circ} \mathrm{C}$ for 5 minutes.

\section{qPCR}

Quantitative PCR was performed in a total reaction volume of $25 \mu 1 . \mathrm{C}_{\mathrm{T}}$ cut off value was adjusted to 35 with positive and negative controls. Distribution of reaction components are $12.5 \mu \mathrm{l}$ of $\mathrm{RT}^{2}$ qPCR master mix, $10.5 \mu \mathrm{l}$ of $\mathrm{ddH}_{2} \mathrm{O}, 1.0 \mu \mathrm{l}$ of template cDNA and $1.0 \mu 1$ of $\mathrm{RT}^{2} \mathrm{qPCR}$ primer assay. Reaction conditions are given in Table 1. The data of the genes and housekeeping gene used in the reaction are given in Table 2. Sybr green was used as fluorescent dye in the reaction (QIAGEN, RT2 SYBR Green qPCR Mastermix, Cat No:330500). In the study, 3 techniques and 3 biological repeats were applied.

\section{Data Analysis}

$\mathrm{C}_{\mathrm{T}}$ values were analyzed with the Qiagen GeneGlobe bioinformatics tool. Fold change and fold regulation values were computed with the $\Delta \Delta \mathrm{C}_{\mathrm{T}}$ method (Livak and Schmittgen, 2001). The floor change between the test and control groups was calculated with the formula $2^{\wedge}$ (delta delta $\mathrm{C}_{\mathrm{T}}$ ). For the statistical significance of the expression change 
between the test and control groups, p value was analyzed by $\mathrm{t}$ test $(\mathrm{p}<0.05)$.

Table 1. qPCR reaction conditions

\begin{tabular}{|c|c|c|}
\hline Cycle & $\begin{array}{c}\text { Temperature } \\
\left({ }^{\circ} \mathrm{C}\right)\end{array}$ & Time \\
\hline 1 & 95 & 10 minute \\
\hline 40 & 95 & 15 second \\
\hline 40 & 53 & 40 second \\
\hline 40 & 72 & 30 second \\
\hline
\end{tabular}

\section{RESULTS AND DISCUSSION}

Pesticide is released into the environment in a controlled manner to prevent, destroy or control undesirable plant or animal species (Zikankuba et al., 2019). Fatty acid-induced signaling is one of the important defense pathways. (Kachroo et al., 2005).

The synthesis of ALA requires the activity of $\omega$ 3 FADs which were encoded by FAD 3 and FAD7 (Peng et al., 2020). In transcriptome analysis with perilla seeds, FAD3 and FAD7 genes were found to be the basic genes for ALA synthesis (Kim et al., 2016). ALA, which is the product of $\omega-3$ FAD is precursor of jasmonic acid that play crucial roles in plant development and stress responses (Weber, 2002).

It has been shown that salicylic acid applications can positively affect the formation of some plant secondary metabolites (such as essential oils, oleoresins and triterpenes) (Elyasi ve ark., 2016; Mirzajani et al., 2015; Rodrigues and Fett-Netto, 2009).

In this study, the data analysis web portal (GeneGlobe ${ }^{\circledR}$ ) calculates fold change/regulation using delta delta CT method, in which delta CT is calculated between genes (FAD3 and FAD7) and a housekeeping gene (HKG). Fold Change is calculated using $2^{\wedge}$ (-delta delta CT). The statistical evaluation of the difference between the expression levels of the $F A D 3$ and FAD7 genes between the test groups and control groups was done with t-test (Table 3). $\mathrm{p}<0.05$ was statistically significant.

The analysis results of the samples at $24^{\text {th }} \mathrm{h}$ were given in Figure 1. FAD3 gene expression was downregulated in all application groups, but only in 0,004 M PEN, 0.004 M PEN+0.5 mM SA and 0.01M groups were statistically significant $(\mathrm{p}<0.05)$ (Table $3)$. It was observed that the downregulate in gene expression level formed with PEN application upregulated even more with SA. In the heat map, there was decrease in $F A D 3$ expression compared to the control group (Figure 1). FAD7 gene expression was downregulated in all groups. This decrease in expression level was found statistically significant except 0,01 M PEN+0,5 mM SA groups. When the effect of SA on control groups was analyzed, it was found that the decrease in $F A D 7$ expression was higher than FAD3. PEN was downregulated FAD3 and $F A D 7$ expression levels. Increasing of PEN concentration caused more decrease in expression level in FAD3 than FAD7.

SA caused a downregulate in FAD3 and FAD7 expression levels on the control group at $48^{\text {th }} \mathrm{h}$. While $F A D 3$ was upregulated in the test groups, FAD7 was downregulated (Figure 1). SA application limited the decrease in FAD7 expression in test groups exposed to pendimethalin (Table 3).

The expression levels of FAD 3 and FAD7 genes were upregulated compared to the control group in PEN and PEN+SA application groups at $72^{\text {th }} \mathrm{h}$ in Dinçer cultivar. (Figure 1). Increases in expression levels were also found statistically significant (Table $3)$.

FAD3 expression in rapeseed under injury stress is known to be stimulated by abscisic acid, a plant growth regulator (Jitao et al., 1995). FAD7 expression was down-regulated in low temperature stress in the leaves of birch seedlings, while $F A D 3$ expression was up-regulated and an increase in ALA content was detected (Martz et al., 2006). Kim et al. (2016) showed that PfrFAD3 and PfrFAD7/8 were identified as key genes for ALA synthesis in seeds and leaves of Perilla frutescens (L.) var. frutescens. Sen Wang et al. (2014) reported that significant changes in fatty acid composition caused by consuming of LeFAD3 in antisense transgenic tomato (Lycopersicon esculentum) lines were the reduce in 18:3 and the rise in 18:2 in leaves and roots. Guan et al. (2014) reported that the low FAD3 transcript level in developing seeds is consistent with the high linoleic acid level and linolenic acid deficiency in safflower seed oil. 
Table 2. Primer sequence of genes

\begin{tabular}{|l|l|}
\hline \multicolumn{1}{|c|}{ Symbol } & \multicolumn{1}{c|}{ Sequence } \\
\hline $\begin{array}{l}\text { ACTB (Housekeeping) } \\
\text { Acc.KJ634809.1 }\end{array}$ & F- GCGGCTGGTATCCACGAGA \\
\hline FAD3 & R- TCAGCAATGCCAGGGAACATAG \\
Acc.HQ831356.1 & F- TCGTGGGTCCCGTTAAATGAAA \\
\hline FAD7 & FCCACAAGTACAATGGGTATGC \\
Acc.HQ831349.1 & F- TCCACCTCACTTCCAAGAGTTG \\
\hline
\end{tabular}

Table 3. Changing in expression levels of $F A D 3$ and $F A D 7$ genes $(\mathrm{p}<0.5)$

\begin{tabular}{|c|c|c|c|c|c|c|c|}
\hline \multirow{4}{*}{$\begin{array}{c}\text { Group } 1 \\
0.5 \text { mM SA Control }\end{array}$} & \multicolumn{4}{|c|}{ FAD 3} & \multicolumn{3}{|c|}{ FAD 7} \\
\hline & \multirow[b]{2}{*}{$\begin{array}{l}\text { Fold } \\
\text { Change }\end{array}$} & $24 \mathrm{~h}$ & $48 \mathrm{~h}$ & $72 \mathrm{~h}$ & $24 \mathrm{~h}$ & $48 \mathrm{~h}$ & $72 \mathrm{~h}$ \\
\hline & & 0.91 & 0.39 & 1.75 & 0.17 & 0.94 & 1.66 \\
\hline & $\mathrm{P}$ value & 0.486 & 0.000 & 0.035 & 0.001 & 0.003 & 0.043 \\
\hline \multirow{2}{*}{$\begin{array}{c}\text { Group } 2 \\
0.004 \text { M PEN }\end{array}$} & $\begin{array}{c}\text { Fold } \\
\text { Change }\end{array}$ & 0.21 & 1.19 & 2.93 & 0.54 & 0.39 & 2.36 \\
\hline & $\mathrm{P}$ value & 0.002 & 0.022 & 0.002 & 0.013 & 0.000 & 0.002 \\
\hline \multirow{2}{*}{$\begin{array}{c}\text { Group 3 } \\
0.004 \text { M PEN+0.5 mM SA }\end{array}$} & $\begin{array}{l}\text { Fold } \\
\text { Change }\end{array}$ & 0.20 & 1.03 & 5.29 & 0.11 & 0.45 & 5.79 \\
\hline & $\mathrm{P}$ value & 0.002 & 0.595 & 0.000 & 0.001 & 0.000 & 0.000 \\
\hline \multirow{2}{*}{$\begin{array}{c}\text { Group } 4 \\
0.01 \mathrm{M} \text { PEN }\end{array}$} & $\begin{array}{l}\text { Fold } \\
\text { Change }\end{array}$ & 0.07 & 2.31 & 2.43 & 0.48 & 0.51 & 13.55 \\
\hline & $\mathrm{P}$ value & 0.000 & 0.006 & 0.015 & 0.002 & 0.000 & 0.0001 \\
\hline \multirow{2}{*}{$\begin{array}{c}\text { Group } 5 \\
0.01 \mathrm{M} \text { PEN+0.5 mM SA }\end{array}$} & $\begin{array}{c}\text { Fold } \\
\text { Change }\end{array}$ & 0.72 & 2.96 & 3.16 & 0.64 & 0.93 & 6.93 \\
\hline & $P$ value & 0.050 & 0.012 & 0.017 & 0.076 & 0.001 & 0.000 \\
\hline
\end{tabular}

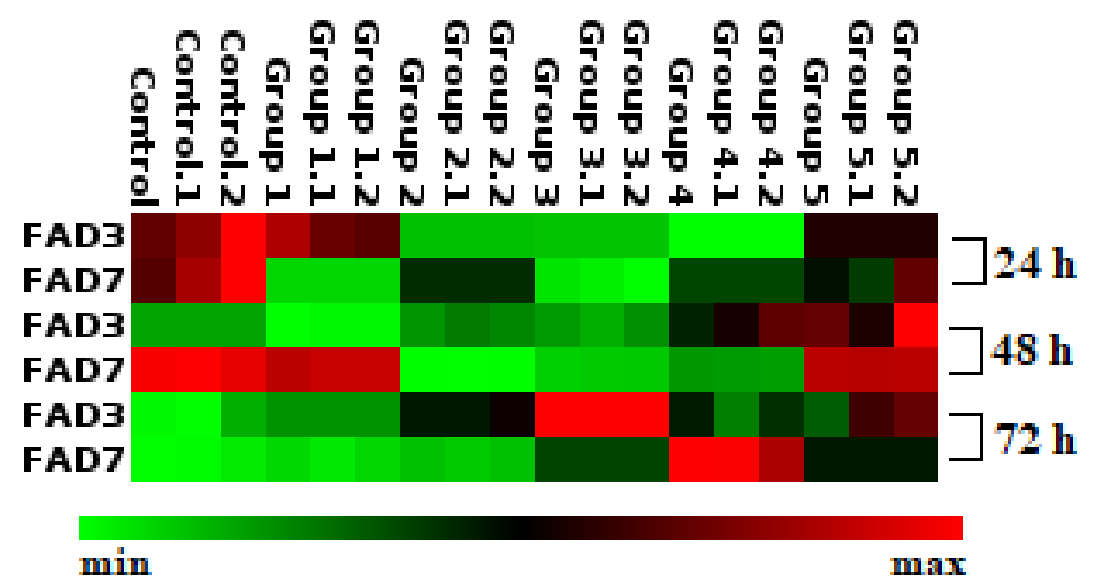

Figure 1. Heatmap showing expression levels of $F A D 3$ and $F A D 7$ genes at $24,48,72^{\text {th }} \mathrm{h}$ 
Safflower is an important industrial plant with oil seed used for edible oil production and its cultivation has been increasing throughout the world in last decades. The plant is a valuable resource in terms of nutrition with its high ALA capacity. It is an important source in nutrition with its high ALA content. It has been demonstrated with this study that herbicides, which are widely used for the purpose of increasing plant production and yield, may exhibit negative results in the oil metabolism of the plant in terms of oil yield. It was also shown that SA played a role in removing negative effects of PEN (Figure 2 and 3).

\section{CONCLUSION}

It is thought that the use of PEN may have a decrease in plantal oil yield in Carthamus tinctorius L. Dinçer cultivar and cause a decrease in ALA formation in terms of nutrition and metabolism. SA can play a role in reducing the adverse effect of PEN on fatty acid metabolism.

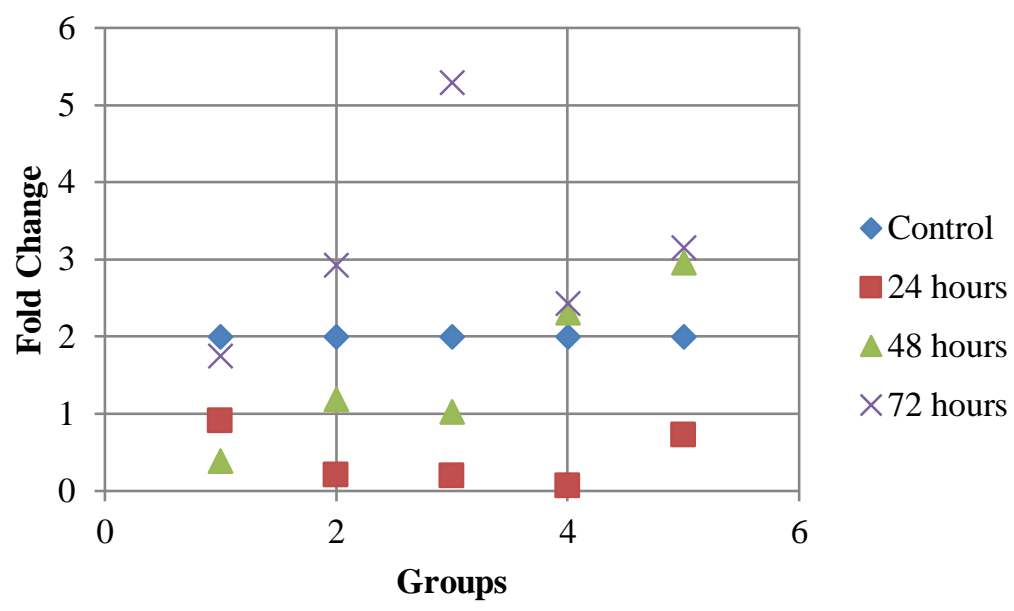

Figure 2. General evaluation of fold change in FAD3 expression levels

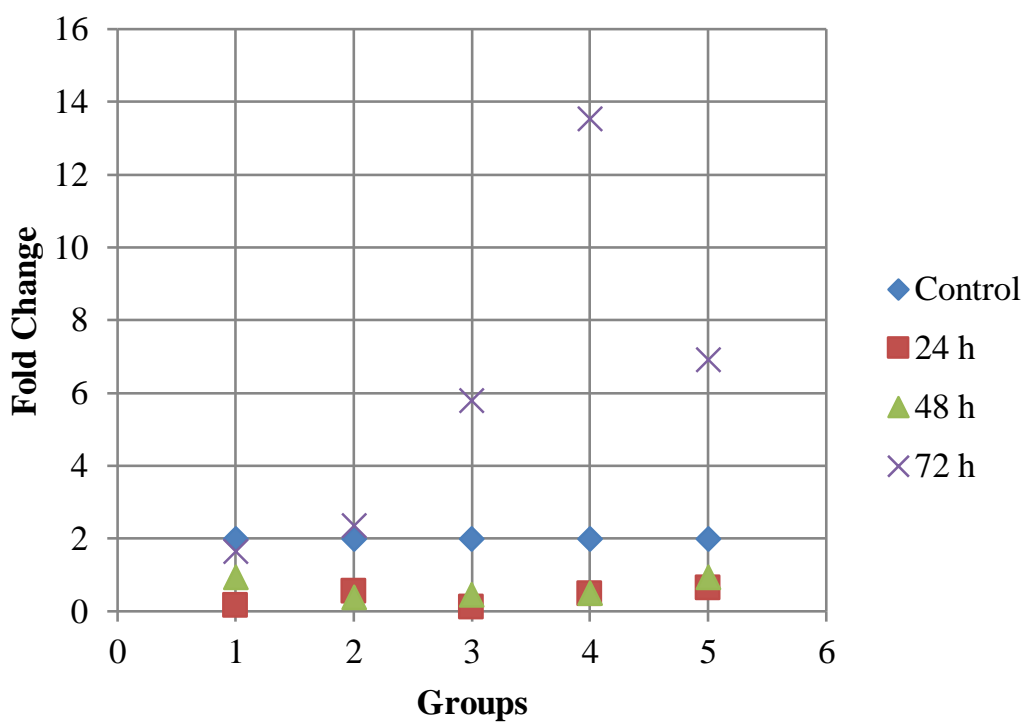

Figure 3. General evaluation of fold change in $F A D 7$ expression levels 


\section{CONFLICT OF INTEREST STATEMENT}

The author declares that there is no conflict of interest in this study.

\section{RESEARCH AND PUBLICATION ETHICS STATEMENT}

The author declares that the research and publication ethics are complied with in the study.

\section{REFERENCES}

Agostinetto, D., Perboni, L.T., Langaro, A.C., Gomes, J., Fraga, D.S., Franco, J.J., 2016. Changes in photosynthesis and oxidative stress in wheat plants submitted to herbicides application. Planta Daninha, 34:1-9.

Andersen, E.J., Ali, S., Byamukama, E., Yen, Y., Nepal, M.P., 2018. Disease resistance mechanisms in plants. Genes (Basel). 9:1-30.

Dajue,L., Mündel, H., 1996. Safflower, Carthamus tinctorius L. pp 83. International Plant Genetic Resources Institute, Rome.

Elyasi, R., Majdi, M., Bahramnejad, B., Mirzaghaderi, G., 2016. Spatial modulation and abiotic elicitors responses of the biosynthesis related genes of mono/triterpenes in black cumin (Nigella sativa). Industrial Crops and Products, 79:240-247.

Fu, Z.Q., Dong, X., 2013. Systemic acquired resistance: turning local infection into global defense. Annual Review of Plant Biology, 64:839-863.

Guan, L.L., Wu, W., Hu, B., Li, D., Chen, J.W., Hou, K., Wang, L., 2014. Devolopmental and growth temperature regulation of omega-3 fatty acid desaturase genes in safflower (Carthamus tinctorius L.). Genetics and Molecular Research, 13:66236637.

Heppard, E.P., Kinney, A.J., Stecca, K.L., Miao, G.H., 1996. Developmental and growth temperature regulation of two different microsomal $\omega-6$ desaturase genes in soybeans. Plant Physiology, 110:311-319.

Hoagland, D.R., Arnon, D.I., 1938. The water-culture method for growing plants without soil: University of California. California Agricultural Experiment Station, 347:32.

Hou, L., Lee, W., Rusiecki, J., Hoppin, J., Blair, A., Bonner, M., Lubin, J., Samanic, C., Sandler, D., Dosemeci, M., Alavanja, M., 2004. Pendimethalin exposure and cancer risk among pesticide applicators: a report from the U.S.-based agricultural health study. Annals of Epidemiology, 14:608.

Jitao, Z., Abrams, G.D., Barton, D.L., Taylor, D.C., Pomeroy, M.K., Abrams, S.K., 1995. Induction of lipid and oleosin biosynthesis by (+)-abscisic acid and its metabolites in microspore-derived embryos of Brassica napus L. cv Reston. Biological responses in the presence of 8'-hydroxyabascisic acid. Plant Physiology, 108:563-571.

Kachroo, P., Venugopal, S.C., Navarre, D.A., Lapchyk, L., Kachroo, A., 2005. Role of salicylic acid and fatty acid desaturation pathways in ssi2-mediated signaling. Plant Physiology, 139:1717-1735.

Kaur, G., 2019. Herbicides and its role in induction of oxidative stress- a review. International Journal of Environment, Agriculture and Biotechnology, 4:995-1004.

Kim, H.U., Lee, K.R., Shim, D., Lee, J.H., Chen, G.Q., Hwang, S., 2016. Transcriptome analysis and identification of genes associated with $\omega-3$ fatty acid biosynthesis in Perilla frutescens L. var. Frutescens. BMC Genomics, 17:1-19.

Livak, K.J., Schmittgen, T.D., 2001. Analysis of relative gene expression data using real-time quantitative PCR and the 2- $\Delta \Delta \mathrm{CT}$ method. Methods, 25:402408.

Los, D.A., Murata, N., 1998. Structure and expression of fatty acid desaturases. Biochimica et Biophysica Acta (BBA)-Lipids and Lipid Metabolism, 1394:315.

Majidi, M.M., Tavakoli, V., Mirlohi, A., Sabzalian, M.R., 2011. Wild safflower species (Carthamus oxyacanthus Bieb.): A possible source of drought tolerance for arid environments. Australian Journal of Crop Science, 5:1055-1063.

Martz, F., Kiviniemi, S., Palva, T.E., Sutinen, M.L., 2006. Contribution of omega-3 fatty acid desaturase and 3-ketoacyl-ACP synthase II (KASII) genes in the modulation of glycerolipid fatty acid composition during cold acclimation in birch leaves. Journal of Experimental Botany, 57:897909.

Maruri-López, I., Aviles-Baltazar, N.Y., Buchala, A., Serrano, M., 2019. Intra and extracellular journey of the phytohormone salicylic acid. Frontiers in Plant Science, 10:423.

Mirzajani, Z., Hadavi, E., Kashi, A., 2015. Changes in the essential oil content and selected traits of sweet basil (Ocimum basilicum L.) as induced by foliar sprays of citric acid and salicylic acid. Industrial Crops and Products, 76:269-274.

Osman, K.A., Salama, A.K., Salama, M.S., Albakary, A.S., 2016. Oxidative stress and pharmacokinetics of pendimethalin in female rats. Journal of Clinical Toxicology, 6:1-6.

Pahlavani, M.H., Mirlohi, A.F., Saeidi, G., 2004. Inheritance of flower color and spininess in safflower (Carthamus tinctorius L.). Journal of Heredity, 95:265-267. 
Peng, Z., Ruan, J., Tian, H., Shan, L., Meng, J., Guo, F., Zhang, Z., Ding, H., Wan, S., Li, X., 2020. The family of peanut fatty acid desaturase genes and a functional analysis of four $\omega-3$ AhFAD 3 members. Plant Molecular Biology Report, 38:209-221.

Rodrigues, K.C.S., Fett-Neto, A.G., 2009. Oleoresin yield of Pinus elliottii in a subtropical climate: Seasonal variation and effect of auxin and salicylic acid-based stimulant paste. Industrial Crops and Products, 30:316-320.

Sen Wang, H., Yu, C., Tang, X.F., Zhu, Z.J., Ma, N.N., Meng, Q.W., 2014. A tomato endoplasmic reticulum (ER)-type omega-3 fatty acid desaturase (LeFAD3) functions in early seedling tolerance to salinity stress. Plant Cell Reports, 33:131-142.

Tomlin, C.D.S., 2001. The e-pesticide manual (version 2.1.). British Crop Protection Council, England.

Weber, H., 2002. Fatty acid-derived signals in plants. Trends Plant Science, 7:217-224.

Xue, Y., Chen, B., Win, A.N., Fu, C., Lian, J., Liu, X., Wang, R., Zhang, X., Chai, R., 2018. Omega-3 fatty acid desaturase gene family from two $\omega-3$ sources, Salvia hispanica and Perilla frutescens: Cloning, characterization and expression. PLoS One, 13:1-25.

Yang, M., Xu, Y., 2007. Oleate accumulation, induced by silencing of microsomal omega- 6 desaturase, declines with leaf expansion in transgenic tobacco. Journal of Plant Physiology, 164:23-30.

Zikankuba, V.L., Mwanyika, G., Ntwenya, J.E., James, A., 2019. Pesticide regulations and their malpractice implications on food and environment safety. Cogent Food and Agricultura, 5:1-15. 